\title{
PENCAPAIAN STANDAR NASIONAL PENDIDIKAN DI SEKOLAH MENENGAH KEJURUAN DAERAH ISTIMEWA YOGYAKARTA
}

\author{
Soeharto \\ FT Universitas Negeri Yogyakarta (e-mail: hart_harto@yahoo.co.id)
}

\begin{abstract}
Abstrak: Pencapaian Standar Nasional Pendidikan di SMK DIY. Sebagai kota yang memperoleh julukan kota pelajar, selayaknya Yogyakarta berwawasan keunggulan, yakni memiliki ketersediaan lembaga pendidikan yang prima. Pendidikan prima berwawasan keunggulan dimiliki jika delapan standar nasional pendidikan dipenuhi yang menyangkut standar isi, proses, kompetensi lulusan, pendidik dan tenaga kependidikan, sarana prasarana, pengelolaan, penilaian, dan standar pembiayaan. Pengukuran ketercapaian standar nasional di lapangan secara legal formal adalah menggunakan perangkat instrumen akreditasi sekolah. Terdapat 137 titik akreditasi pada 2009 di seluruh DIY. Melalui pengolahan data yang ada di kantor BAN SM dan BAP SM DIY, dianalisis butir per butir yang tergolong pada tiap standar diperoleh hasil pencapaian tiap standar. Pencapaian Standar Isi dihitung dari banyaknya sekolah/program keahlian yang menjawab A dibagi dengan jumlah keseluruhan titik akreditasi $=0.71$. Dengan cara yang sama terukur pencapaian Standar Proses sebesar 0.66, Standar Kompetensi Lulusan sebesar 0.57, Standar Pendidik dan Tenaga Kependidikan 0.69, Standar Sarana Prasarana 0.70, Standar Pengelolaan 0.67, Standar Pembiayaan 0.83, Standar Penilaian Pendidikan 0.74 .
\end{abstract}

Kata Kunci: pencapaian Standar Nasional Pendidikan, Sekolah Menengah Kejuruan

\begin{abstract}
The Achievement of National Standard at Vocational High School in DIY. As a city that given nickname by student city, Yogyakarta should be a city with a special quality of conception, and has some great education institutions for elementary and high school level. This great and special quality will be fated, if the description of national standard education can be reach maximally. The measurement of reliable description for national standard education based on legal formal and some facts in the field by using data that revealed through instrument and accreditation systems. The amount of data through research is 137 accreditation points across DIY. Using secondary data analysis by exploiting data in BAN SM and BAP SM DIY, data then is analyzed in items for every standard. The result of the research shows that achievement of content standard count from the amount of skills school that answered A divided with the number of all skill's program /school=0.71. By using the same ways, the measurement of achievement in process standard is 0.66 ; the achievement of standard graduate competence is 0.69 ; the achievement of standard instrument and infrastructure are 0.70 ; the
\end{abstract}


achievement of standard management is 0.67 ; the achievement of funding standard is 0.83 ; the achievement of appraisal in education 0.74 .

Keywords: achievement of national standard of education, vocational school

\section{PENDAHULUAN}

Slavin (2008) menegaskan bahwa mengevaluasi program pendidikan hendaknya memperhatikan berbagai hal: "how to review to provide unbiased, scientifically validand useful information that educators and policy makers can use to make wide decisions to benefit children." Melalui cara pandang Slavin (2008) tersebut, diharapkan penelitian yang berintikan pada pencapaian delapan standar nasional pendidikan ini dapat dijadikan masukan bagi pengambil keputusan pembinaan Sekolah Menengah Kejuruan, baik pada aras Direktorat Jenderal di lingkungan Kemdikbud, Dinas Pendidikan Provinsi dan bahkan sampai Dinas Pendidikan Kabupaten. Delapan standar nasional yang dimaksud adalah standar isi, proses, kompetensi lulusan, pendidik dan tenaga kependidikan, sarana prasarana, pengelolaan, pembiayaan, dan penilaian pendidikan.

Penggunaan delapan standar nasional sebagai tolok ukur, sejalan dengan Burko, Wolf, Simons, dan Uchiyana (2003) yang mengukur kapasitas pendidikan melalui enam dimensi, yakni principal leadership, professional community, program coherence, technical resources, knowledge, skills, and dispositions of individual teachers, and learning opportunities for teachers. Penekanan ke enam dimensi tersebut lebih berorientasi pada guru dan tenaga kependidikan, sedangkan koherensi program dimaknakan mencakup pada tujuh standar lainnya.

UU 20 tahun 2003 tentang Sisdiknas menyiratkan bahwa pendidikan yang prima dan berwawasan keunggulan dapat dilaksanakan, bilamana lembaga pendidikan sedikitnya telah memenuhi delapan standar pendidikan nasional. Oleh karenanya, langkah pertama untuk menentukan seberapa baik layanan pendidikan, dilakukan dengan mengukur seberapa banyak ketercapaian standar pendidikan nasional tersebut.

Upaya untuk mengukur ketercapaian standar pendidikan nasional di Sekolah Menengah Kejuruan (SMK) terkendala karena dua hal. Pertama, secara provinsial apalagi nasional, pengambilan data yang dilakukan oleh tim independen yang bebas kepentingan. Kedua, pemanfaatan data yang bersumber bottom up (misal dari proposal blockgrant, dana bantuan operasional siswa, peralatan laborat dan bengkel, dan rehabilitasi kelas) tidak cukup objektif, karena sebagian sekolah pengusul cenderung merekayasa data untuk kepentingan sesaat dalam proposal pengajuan dana bantuan.

Upaya yang ditempuh untuk meretas kendala tersebut dengan menggunakan data akreditasi sekolah yang dilaksanakan oleh badan independen karena memiliki kapabilitas untuk itu. 
Walaupun demikian, data dari badan tersebut masih perlu diolah dan dipadukan dengan data dari stake holder lainnya.

Akreditasi yang dilakukan oleh pihak ketiga dapat memandu pengembangan dan perawatan yang berhubungan antara akuntabilitas dan pengembangan sistem pendidikan. Melalui pemenuhan organisasi dan pelaksanaan program yang baku akan diperoleh layanan pendidikan yang berkesinambungan, efektif, dan efisien. Lembaga akreditasi yang secara berkesinambungan memberikan umpanbalik dari dan untuk pengguna stakeholders, professional, dan asosiasi untuk memberikan jaminan bahwa proses akreditasi dan proses mereviu merefleksikan pelaksanaan akreditasi yang terpercaya. Narasi di atas dikutip dari situs resmi Universitas British Columbia (http://www.mcf.gov.bc.ca/accreditation/index.htm).

Gaff dalam artikel yang berjudul Academic Freedom and Accreditation yang ditampilkan pada 2010 Annual Conference Council for Higher Education Accreditation di Washington DC tanggal 27 Januari 2010, berpendapat bahwa kebebasan akademik adalah bagian penting dari pencarian intelektual dalam penelitian dan pengajaran. Melalui pengalaman dari sejarah peradaban keilmuan, ditemukan bahwa kebebasan akademis akan menuntun penelitian sebagai wahana untuk menemukan tulisan-tulisan ilmiah yang dipertahankan melalui debat ilmiah, sehingga diperoleh kemajuan ilmu pengetahuan". Lalu apa hubungan antara akreditasi dengan kebebasan akademik? Akreditasi lembaga pendidikan adalah prasyarat penjaminan mutu pendidikan yang menjamin terlahirnya kebebasan akademik.

Akreditasi yang dilakukan oleh pihak ketiga dapat menumbuhkembangkan kepercayaan bahwa pengukuran akreditasi tersebut berjalan fair, sehingga data yang disajikan dari badan akreditasi dapat dipercaya sebagai upaya memperoleh data agregat yang sebenarnya. Ini sebagai dasar peneliti memberanikan diri menggunakan data dari pihak ketiga, khususnya dari Badan Akreditasi Nasional Sekolah/ Madrasah (selanjutnya disingkat BAN SM), sebagai bahan data sekunder yang diteliti. Eksistensi BAN SM secara legal formal dijamin oleh Permendiknas 29/2005 tentang Badan Akreditasi Nasional Sekolah/Madrasah.

Dari buku Kebijakan Akreditasi yang diterbitkan oleh BAN SM diperoleh informasi sebagai berikut. Mengacu pada Peraturan Pemerintah No. 19 Tahun 2005 Pasal 91 disebutkan bahwa setiap satuan pendidikan wajib melakukan penjaminan mutu pendidikan. Penjaminan mutu pendidikan bertujuan untuk memenuhi atau melampaui Standar Nasional Pendidikan. Penjaminan mutu pendidikan dilakukan secara bertahap, sistematis, dan terencana dalam suatu program penjaminan mutu yang memiliki target dan kerangka waktu yang jelas. Dalam Permendiknas No. 63 Tahun 2009 tentang Sistem Penjaminan Mutu Pendidikan (Pasal 43 ) disebutkan bahwa semua sekolah/madrasah wajib mengikuti akreditasi yang diselenggarakan oleh BAN-SM. Dalam implementasinya, 
kegiatan penjaminan mutu dilakukan secara sinergis oleh berbagai pihak, baik pihak internal, maupun pihak eksternal.

Undang-undang No. 20 Tahun 2003 tentang Sistem Pendidikan Nasional, Bab XVI Bagian Kedua pasal 60 tentang Akreditasi, berbunyi sebagai berikut.

- Akreditasi dilakukan untuk menenukan kelayakan program dan satuan pendidikan pada jalur pendidikan formal dan nonformal pada setiap jenjang dan jenis pendidikan.

- Akreditasi terhadap program dan satuan pendidikan dilakukan oleh lembaga mandiri yang berwenang sebagai bentuk akuntabilitas publik.

- Akreditasi dilakukan atas dasar kriteria yang bersifat terbuka.

- Untuk melaksanakan mandat perundangan tersebut, Menteri Pendidikan Nasional selanjutnya menerbitkan Peraturan Mendiknas No. 29 Tahun 2005 tentang Badan Akreditasi Nasional Sekolah/Madrasah. Dalam pasal 1 ayat (1) Peraturan Mendiknas tersebut dinyatakan bahwa BAN-SAM adalah badan evaluasi mandiri yang menetapkan kelayakan program dan/atau satuan pendidikan jenjang pendidikan dasar dan menengah jalur formal dengan mengacu pada Standar Nasional Pendidikan.

Chatterji (2008) menyebutkan bahwa metode untuk mempersiapkan reviu dan efektivitas pendidikan bergantung pada kriteria metodologi di dalamnya yang mengukur dan melaporkan dampaknya secara tajam berdasar pengalaman. Dengan mengambil pandangan Chatterji (2008) tersebut, data dari BAN SM yang merupakan badan penjaminan mutu eksternal dapat dijadikan sebagai kriteria yang tepat untuk mengukur dan melaporkan efektivitas pendidikan. Dengan kata lain, data akreditasi dapat dijadikan sumber pengambilan keputusan yang tepat.

\section{METODE}

Penelitian ini menggunakan data sekunder yang diambil di BAN SM Jakarta dan BAP SMProv DIY. Data yang diperoleh diolah terlebih dahulu disesuaikan dengan kepentingan penelitian. Jumlah SMK di Daerah Istimewa Yogyakarta adalah 191, dengan komposisi 49 berstatus negeri dan 142 berstatus swasta. Bila tiap sekolah memiliki tiga program keahlian, diperoleh populasi sejumlah 573 program keahlian. Jumlah program keahlian yang diteliti dengan menggunakan data sekunder 137 program keahlian atau 137 titik akreditasi. Dengan demikian, diperoleh sampling rasio 1:3. Pengambilan titik akreditasi dilakukan oleh Dinas Pendidikan Provinsi DIY. Hakekatnya, diutamakan pada titik akrediatsi yang belum diakreditasi atau habis akreditasinya pada akhir tahun 2008.

\section{HASIL}

\section{Standar Isi}

Pemberlakuan Standar Isi untuk SMK berdasar Peraturan Mendiknas 22/2006 tentang Standar Isi untuk Satuan Pendidikan Dasar dan Menengah. Standar Isis mengamanahkan bahwa pelaksaan kurikulum harus sesuai konsep KTSP, yakni memiliki sembilan 
muatan, yang dikembangkan dengan melibatkan unsur guru, dunia usaha dan dunia industri, dan melalui mekanisme yang baku dengan tujuh kegiatan pokok. Di samping hal tersebut, program Praktik Kerja Industri dilaksanakan sesuai alokasi waktu 2 bulan, dengan mengikuti jadwal kerja karyawan/pegawai. Lama waktu belajar per sks sesuai dengan permintaan standar isi adalah ( 1 jam = 45 menit, 1 minggu $=36$ jam, 1 tahun = 38 minggu), dengan pengayaan; sedang $7.80 \%$ lainnya sesuai ketentuan tanpa pengayaan. Selain hal tersebut, pada saat mengembangkan silabus program keahlian harus menjamin pemenuhan tujuh langkah yang baku, dan penentuan KKM yang memperhatikan tiga unsur yakni:siswa, mata pelajaran, dan kondisi program keahlian. Terakhir, program keahlian harus menjadwalkan awal tahun pelajaran, minggu efektif belajar, waktu pembelajaran efektif, dan hari libur.

Hasil penelitian menunjukkan bahwa tidak semua ketentuan Standar Isi diatas terpenuhi,dalam bentuk tabel sebagai berikut.

Tabel 1. Keterpenuhan Standar Isi

\begin{tabular}{llc}
\hline No. & \multicolumn{1}{c}{ Substansi } & Ya \\
\hline 1. & Pelaksaaan kurikulum sesuai konsep KTSP & 82.48 \\
2. & KTSP dikembangkan melibatkan unsur terkait, seperti guru, dunia usaha, & 67.88 \\
& dunia industri, konselor, komite sekolah dan pihak sekolah & \\
3. & Kurikulum dikembangkan sesuai mekanisme penyusunan KTSP & 60.58 \\
4. & Program Prakerin sesuai alokasi waktu & 97.08 \\
5. & Waktu belajar per sks sesuai prosedur & 89.78 \\
6. & Pengembangan silabus sesuai prosedur Pengembangan silabus sesuai & 81.75 \\
& prosedur & \\
7. & Penentuan Kriteria Kelulusan Minimal sesuai prosedur & 86.86 \\
8. & Kepemilikan Kalender akademik & 96.35 \\
\hline
\end{tabular}

Rata-rata keterpenuhan standar isi adalah 0.71 . Artinya, hanya $71 \%$ yang benar benar melaksanakan pembelajaran sesuai dengan ketentuan yang ada pada standar isi. Masih terdapat celah kekurangan 29\% karena mereka belum taat asas. Tentu kadar ketidaktaatan asas tiap sekolah bahkan tiap kabupaten/kota dengan kadar yang berbeda-beda.

\section{Standar Proses}

Pemberlakuan Standar Proses berdasar Peraturan Mendiknas No. 41 Tahun 2007 tentang Standar Proses untuk Satuan Pendidikan Dasar dan Menegah. Standar proses mengamanahkan bahwa RPP yang dikembangkan oleh guru harus memuat 11 hal, dengan persyaratan proses pembelajaran per rombongan maksimal 32 siswa, dengan beban mengajar guru sekurang-kurangnya 24 jam tatap muka, memiliki buku teks yang cukup (rasio buku siswa 1:1). Langkah pembelajaran selayaknya terstruktur yang mencakup kegiatan pendahuluan, inti, dan penutup yang jelas; yang dibantu dengan penerapan Teknologi Informasi dan Komunikasi (TIK). Sebagai tahap akhir 
dalam standar proses adalah pemantauan dan supervisi sejak perencanaan, pelaksanaan, dan penilaian hasil pembelajaran. Purwaningsih (2008) menyatakan bahwa tiga langkah pembelajaran berbasis proyek dengan jejak kasus, yang dirancang dalam RPP, berhasil memompa motivasi berprestasi siswa dalam pembelajaran. Selengkapnya, hasil penelitian menunjukkan hal-hal sebagai berikut.

Table 2. Keterpenuhan Standar Proses

\begin{tabular}{|c|c|c|}
\hline No. & Substansi & Ya \\
\hline 1. & Mapel disusun secara lengkap dan sistematis & 92.70 \\
\hline 2. & $\begin{array}{l}\text { Persyaratan pemelajaran sesuai aturan (maks } 32 \text { sisa/kelas, beban } \\
\text { mengajar guru minimum } 24 \mathrm{jam} / \mathrm{minggu} \text {, buku teks pelajaran 1:1) }\end{array}$ & $47: 45$ \\
\hline 3. & Proses pembelajaran terdiri atas 3 langkah (pendahuluan inti, penutup) & 85.40 \\
\hline 4. & $\begin{array}{l}\text { Pembelajaran dibantu dengan guru yang handal dan memiliki } \\
\text { kemampuan TIK }\end{array}$ & 76.64 \\
\hline 5. & Memiliki dan memanfaatkan unit Business Center & 48.18 \\
\hline 6. & Lokasi Prakerin yang relevan & 94.16 \\
\hline 7. & Adanya pentahapan pemantauan & 68.61 \\
\hline 8. & Adanya pentahapan supervisi & 55.47 \\
\hline
\end{tabular}

Di samping itu, hal penting dalam standar proses di SMK adalah Bussiness Center dan Prakerin yang relevan. Menurut de Witt dan Hohenstein (2010) melalui penelitian di Kings College London tentang kunjungan ke luar sekolah seperti ke museum, perpustakaan, DUDI, business center, dapat menjadikan pemahaman siswa dalam substansi belajar akan lebih kompleks sehingga diyakini mampu meningkatkan interaksi antara guru dan siswa.

Pencapaian standar proses adalah = 0.66 , artinya hanya 66\% program keahlian yang melaksanakan PBM sesuai dengan panduan standar proses. Masih terdapat celah $34 \%$ yang perlu diupayakan menuju standar.

\section{Standar Kompetensi Lulusan}

Standar Kompetensi Lulusan mengacu Permendiknas No. 23 dan 24 Tahun
2006 tentang Standar Kompetensi Satuan Pendidikan Dasar dan Menengah. Standar Kompetensi Lulusan menyebutkan kompetensi lulusan dapat dideteksi dengan keberadaan jejak-jejak pembentuk kompetensi lulusan. Jejak tersebut berupa bukti pengalaman belajar, baik yang berujud dokumen, kelompok kajian, praktik pemanfaatan lingkungan, pameran seni kria, kegiatan terprogram ekstra kurikuler, pertandingan olah raga, upacara hari besar, aktivitas ibadah, seni dan tari, debat, serta berkas-berkas mengajar. Prestasi nilai rata-rata UN untuk teori dan ujian praktik produksi, uji kompetensi, dan persentase lulusan tahun terakhir termasuk dipertimbangkan. Berikut adalah perolehan Standar Kompetensi Lulusan. 
Tabel 3. Keterpenuhan Standar Kompetensi Lulusan

\begin{tabular}{llc}
\hline No. & \multicolumn{1}{c}{ Substansi } & Ya \\
\hline 1. & Adanya dokumen berfikir logis dalam pengambilkan keputusan & 16.79 \\
2. & Adanya dokumen diskusi analisis dan pemecahan masalah kompleks & 54.74 \\
3. & Adanya dokumen pengalaman belajar adaptif & 73.72 \\
4. & Adanya dokumen pembiasaan mencari sumber informasi & 64.23 \\
5. & Adanya dokumen pembiasaan memanfaatkan lingkungan dengan bijak & 58.85 \\
6. & Adanay dokumen ekspresi budaya & 59.85 \\
7. & Adanya dokumen pengalaman belajar bersikap percaya diri & 76.64 \\
8. & Adanya dokumen pembiasaan bersikap kompetitif & 70.80 \\
9. & Adanya dokumen pembiasaan kehidupan beragama & 89.05 \\
10. & Adanya dokumen pembiasaan kehidupan multi etnik & 75.91 \\
11. & Adanya dokumen pengalaman belajar membaca dan menulis & 57.66 \\
12. & Adanya dokumen pengalaman belajar ipteks & 62.04 \\
13. & Adanya dokumen pengalaman belajar kewirausahaan & 66.42 \\
14. & Program keahlian memiliki prestasi pada mapel produktif & 13.87 \\
15. & Program keahlian memiliki prestasi diatas 1 nilai rata UN pada mapel & 13.14 \\
& Matematik & \\
16. & Program keahlian memiliki prestasi diatas 1 nilai rata UN pada mapel & 10.22 \\
& Bahasa Inggris & \\
17. & Program keahlian memiliki prestasi diatas 1 nilai rata UN pada mapel & 7.30 \\
& Bahasa Indonesia & \\
18. & Program keahlian memiliki prestasi pada presentase tingkat kelulusan & 89.05 \\
\hline
\end{tabular}

Pencapaian standar Kompetensi Lulusan (SKL) adalah $=0.57$ artinya hanya $57 \%$ program keahlian yang memiliki bukti-bukti pembentukan standar kompetensi lulusan. Masih terdapat celah $43 \%$ yang perlu diupayakan standar.

Cohen, Raudenbush, dan Deborah (2003) menegaskan bahwa banyak peneliti yang melakukan studi hubungan antara sumber daya sekolah dan prestasi belajar siswa menggunakan model sebab akibat. Sumber daya konvensional merupakan agen hambatan pembelajaran, sehingga berdampak pada prestasi belajar mengajar yang moderat atau berprestasi tidak maksimum.

\section{Standar Pendidik dan Tenaga Kepen- didikan}

Standar Teknik di sekolah berdasar Peraturan Mendiknas No. 13 Tahun 2007 tentang Standar Kepala Sekolah/ Madrasah, dan Standar Kualifikasi dan Kompetensi Guru berdasar Peraturan Mendiknas No. 16/2007. Standar ini menekankan adanya latar belakang pendidikan dan kualifikasi kepakaran. Terpenting bagi guru kejuruan adalah kualifikasiakademik, kesesuaian mengajar dengan latar belakang pendidikan, guru mapel produktif dengan jumlah rombel, kesesuaian dengan prinsip pembelajaran, guru produktif memiliki sertifikat keahlian teknik. Di sisi lain, untuk Kepala program keahlian 
berbagai hal pokok yang menjadi kelemahan adalah sertifikat pendidik, kualifikasi akademik, pengalaman kerja, kemampuan berwirausaha, dan melakukan monev. Tenaga administrasi, tenaga perpustakaan, teknisi laboratorium, laboran, dan teknisi perbaikan perawatan ditingkatkan kualifikasi pendidiknya.

Tabel 4. Keterpenuhan Standar Pendidik dan Tenaga Kependidikan

\begin{tabular}{llc}
\hline No. & Substansi & Ya \\
\hline 1. & Kualifikasi akademik minimum guru & 91.97 \\
2. & Kesusuaian mapel dengan latar belakang pendidikan guru & 92.70 \\
3. & Jumlah guru produktif setara dengan jumlah rombel & 94.16 \\
4. & Kepatuhan guru terhadap prinsip pembelajaran & 80.19 \\
5. & Kepemilikan sertifikat keahlian pada guru produktif & 35.04 \\
6. & Kepemilikan kompetensi minor mayor & 63.50 \\
7. & Kualifikasi akademik kaproahlian & 91.97 \\
8. & Pengalaman manajerial kaproahlian & 47.45 \\
9.. & Kemampuan berwirausaha kaproahlian & 31.39 \\
10. & Kualifikasi akademik tenaga administrasi & 86.86 \\
11. & Kualifikasi akademik tenaga pustakawan & 35.04 \\
12. & Kualifikasi kalab/kabeng & 40.88 \\
13. & Kualifikasi laboran & 45.26 \\
14. & Kualifikasi tenaga maintenance peralatan dan gedung & 52.55 \\
\hline
\end{tabular}

Pencapaian standar teknik adalah = 0.69. Artinya, hanya $69 \%$ program keahlian yang memenuhi persyaratan sesuai standar tendik. Masih terdapat celah 31\% yang perlu diupayakan menuju standar.

James dan Vince (2001) menegaskan bahwa kunci permasalahan tendik adalah pada kepemimpinan ketua program keahlian ketua jurusan, kepala sekolah, kepala laboratorium, kepala bengkel, dan kepala perpustakaan yang berupaya menyeimbangkan proyeksi dan ekspektasi, keterlibatannya menyampaikan dan membakukan batasan yang jelas, kepmimpinan yang melibatkan nurani pada saat mengorgani- sasi sekolah saban hari, dan kesediaan untuk menerima kenyataan komentar good enough dari pada berupaya untuk melakukan pekerjaan sesmpurna mungkin.

\section{Standar Sarana Prasarana}

Standar sarana prasarana berlaku berdasarkan Surat Keputusan Direktur Pembinaan Sekolah Menengah Kejuruan yang pada saat penelitian dilaksanakan sedang diajukan untuk memperoleh pengesahan Permendiknas. Pencapaian standar sarana prasarana tercatat $=0.70$ adapun selengkapnya skor perolehan pada aspek sarana prasarana sebagai berikut. 
Tabel 5. Keterpenuhan Standar Sarana dan Prasarana

\begin{tabular}{lll}
\hline No. & Substansi & Ya \\
\hline 1. & Luas lahan memenuhi \\
2. & Lingkungan fisik sekolah memenuhi \\
3. & Memiliki izin peruntukan tanah & \\
4. & Luas bangunan memenuhi \\
5. & Rasio buku teks (1 teks/mapel/siswa) \\
6. & Fasilitas listrik memenuhi \\
7. & Memiliki izin peruntukan bangunan \\
8. & Menyelenggarakan pemeliharaan bangunan \\
9. & Kepemilikan sarpras pada ruang pembelajaran umum \\
10. & Kepemilikan sarpras pada ruang penunjang \\
11. & Kepemilikan sarpras pada ruang pembelajaran khusus \\
12. & Kepemilikan busines center \\
13. & Kepemilikan bursa kerja khusus \\
\hline
\end{tabular}

Pencapaian standar Sarpras adalah $=0.70$ artinya hanya $70 \%$ program keahlian yang memenuhi persyaratan sesuai standar Sarpras. Masih terdapat celah 30\% yang perlu diupayakan menuju ketercapaian standar Sarana Prasarana yang dikeluarkan Direktorat Pembinaan SMK.

\section{Standar Pengelolaan}

Sebagai suatu organisasi sekolah harus memiliki visi, misi, uraian tugas, mekanisme kerja, rencana kerja tahunan. Pengelolaan sekolah mencakup aspek siswa, kurikulum pembelajaran, tendik, sarana prasarana, dan pembiayaan. Di samping itu, juga kemitraan dengan dunia usaha dunia industri, pelatihan bagi teknisi, serta penerapan sistem jaminan mutu, kinerja bursa kerja khusus, kinerja busines center, tendik dan sistem informasi manajemen.
Pencapaian standar pengeloaan sebesar 0.67 , dengan kata lain, hanya $67 \%$ program keahlian yang diakreditasi yang memenuhi standar pengelolaan. Perolehan skor untuk standar pengelolaan dapat dilihat pada Tabel 6.

\section{Standar Pembiayaan}

Penerapan pembiayaan dilaksanakan pada tingkat sekolah, dengan demikian seluruh aspek pembiayaan ditanyakan pada tingkat sekolah. Pencapaian Standar Pembiayaan mencapai 0.83, dengan kata lain hanya $83 \%$ sekolah yang diakreditasi yang mememnuhi Standar Pembiayaan. Garis besar standar ini mengatur penyelenggaraan keuangan dengan membagi ke dalam tiga unsur utama keuangan, yakni: investasi, operasional dan gaji. Perolehan skor aspek pembiayaan dapat dilihat pada Tabel 7. 
Tabel 6. Keterpenuhan Standar Pengelolaan

\begin{tabular}{llc}
\hline No. & Substansi & Ya \\
\hline 1. & Memiliki visi organisasi yang tersosialisasikan & 83.21 \\
2. & Memiliki misi organisasi yang tersosialisasikan & 81.75 \\
3. & Memiliki rumusan tujuan organisasi yang trsosialisasikan & 83.21 \\
4. & Memiliki rencana jangka panjang & 76.64 \\
5. & Memiliki pedoman yang mengatur aspek pengelolaan & 79.56 \\
6. & Memiliki struktur organisasi dengan kejelasan uraian dan tugas & 84.67 \\
7. & Memiliki kegiatan kesiswaan & 87.59 \\
8. & Melaksanakan 4 program pengembangan kurikulum dan pembelajaran & 87.69 \\
9. & Melaksanakan program pendayagunaan tendik & 66.42 \\
10. & Mengelola program sarana prasarana pembelajaran & 62.77 \\
11. & Mengelola program pengelolaan pembiayaan pembelajaran & 68.81 \\
12. & Membangun program kemitraan dengan lembaga lain & 82.48 \\
13. & Memiliki kerjasamadengan dunia usaha dan dunia industri & 32.85 \\
14. & Menerapkan sistem manajemen mutu & 32.12 \\
15. & Memiliki bisnis center yang sesuai & 48.91 \\
16. & Memiliki bursa kerja khusus yang mampu menyalurkan lulusan & 33.58 \\
17. & Melaksanakan kegiatan evaluasi diri & 51.82 \\
\hline
\end{tabular}

Tabel 7. Keterpenuhan Standar Pembiayaan

\begin{tabular}{llc}
\hline No. & \multicolumn{1}{c}{ Substansi } & Ya \\
\hline 1. & Sekolah memiliki catatan tahunan berupa dokumen investasi sarpras & 89.05 \\
2. & Sekolah membelanjakan biaya tendik berdasar RKA & 81.02 \\
3. & Sekolah memiliki modal kerja yang tertuang dalamRKA & 98.54 \\
4. & Sekolah membayar gaji,honor, insentif bagi guru & 100 \\
5. & Sekolah membelanjakan dana untuk kesiswaan & 88.32 \\
6. & Sekolah membelanjakan dana untuk ATK & 88.32 \\
7. & Sekolah membelanjakan biaya alat habis pakai & 85.40 \\
8. & Sekolah membelanjakan biaya penggandaan soal ulangan/ujian & 95.62 \\
9. & Sekolah membelanjakan biaya untuk menunjang kegiatan prakerin, uji & 82.48 \\
& kompetensi, bimbingan karir, dan program kewirausahaan & \\
10. & Sekolah melakukan subsidi silang & 51.09 \\
11. & Pengelolaan dana secara transparan, efisien, dan akuntabel & 90.51 \\
12. & Pedoman pengelolaan keuangan sebagai dasar dalampenyususnan RKA & 80.29 \\
13. & Adanya buku kas umum & 91.24 \\
14. & Sekolah melaksnakan laporan pertanggungan jawab keuangan & 89.78 \\
\hline
\end{tabular}

Berbagai aspek untuk meningkatkan lagi keterpenuhan standar pembiayaan adalah dengan mengenal sumber daya keuangan, pembukaan keuangan yang tertib, pengetahuan dan skill pengelolaan keuangan yang transparan, efisien, dan akuntabel. 


\section{Standar Penilaian}

Standar Penilaian untuk SMK berdasarkan Peraturan Mendiknas No. 20 Tahun 2007 tentang Standar Penilaian Pendidikan. Pencapaian standar ini mencapai 0.74. Dengan kata lain, hanya $74 \%$ program yang diakreditasi yang memenuhi standar pembiayaan. Fokus dari penilaian, teknik dan instrumen, mekanisme prosedur, penilaian oleh satuan pendidikan, dan penilaian oleh pemerintah. Berikut ini adalah perolehan skor aspek penilaian.

Tabel 8. Keterpenuhan Standar Penilaian

\begin{tabular}{|c|c|c|}
\hline No. & Substansi & Ya \\
\hline 1. & Rancangan dan kriteria penilaian tercantum pada silabus & 71.53 \\
\hline 2. & Teknik penilaian dengan indikator pencapaian kompetensi dasar & 77.37 \\
\hline 3. & Pengembangan instrumen xesuai dengan bentuk teknik penilaian & 64.23 \\
\hline 4. & Teknik penilaian sesuai dengan karakteristik mapel & 70.80 \\
\hline 5. & Guru mengolah hasil penilaian untuk diagnostik kesulitan belajar & 68.81 \\
\hline 6. & Guru memanfaatkan hasil penilaian untuk perbaikan pembelajaran & 62.04 \\
\hline 7. & $\begin{array}{l}\text { Program keahlian mengkoordinasikan berbagai bentuk ulangan/ } \\
\text { evaluasi }\end{array}$ & 70.80 \\
\hline 8. & $\begin{array}{l}\text { Program keahlian selenggarakan ujian semester sesuai standar } \\
\text { operasional prosedur }\end{array}$ & 91.97 \\
\hline 9. & $\begin{array}{l}\text { Prora keahlian melaporkan hasil penilaian setiap akhir semester kepada } \\
\text { orang tua }\end{array}$ & 96.35 \\
\hline 10. & Program keahlian menentukan kelulusan siswa dari satuan pendidikan & 71.53 \\
\hline 11. & Uji kompetensi melibatkan berbagai pihak & 81.75 \\
\hline
\end{tabular}

Rata-rata perolehan aspek standar penilaian sudah tinggi, kalaupun yang terasa rendah adalah pada pemanfaatan hasil penilaian untuk diagnosik kesulitan belajar siswa baru sebatas $(68.81 \%)$, dan memanfaatkan hasil penilaian untuk diagnostik perbaikan pembelajaran (62.04).

Pendayagunaan data yang menyeluruh dan mendetail diperlukan dalam pemetaan kualitas pendidikan. Data yang baik diawali dengan perangkat instrumen yang valid dan reliabel, penilai yang memiliki kemampuan dan beretika, serta pusat data yang tangguh. Selanjutnya, data tersebut pada saatnya harus dapat dilacak ulang, untuk ditindak-lanjuti seberapa besar jarak ketidakterpenuhannya. Dengan demikian mudah diketahui kelebihan yang dimiliki oleh sekolah tertentu atau untuk daerah tertentu; serta kekurangan yang harus ditambahkannya.

Penyebab tidak tercapainya tiap standar berbeda-beda. Oleh karena itu, solusi sebaiknya dilacak satu per satu. Pada pencapaian standar isi di SMK bertumpu pada enam aspek, yakni KTSP, Ekskul, Prakerin, Teknik Informasi dan Komunikasi, KKM, dan kalender akademik. Dari aspek tersebut tidak seluruhnya memberi urunan yang sama terhadap ketidaktercapaian. Pencapaian KTSP sudah baik (82.74\%), responden melaksanakan sembilan muatan, dan $85.40 \%$ sekolah sudah 
menyiapkan KTSP sesuai prosedur; tetapi perlu dipertanyakan plagiasi KTSP yang ditengarai marak terjadi. Saran yang diajukan adalah mengupayakan agar bukti KTSP lebih mengarah pada proses bukan berkas fisik KTSP.

Pencapaian standar proses di SMK bertumpu pada perencanaan, pelaksanaan, penilaian, dan pengawasan proses pembelajaran. Aspek terbaik yang diperoleh pada data prakerin (94.16\% sekolah yang memiliki 76-100\% siswa ikut prakerin); saran yang diajukan justru tidak pada kuantitas capaian, tetapi kualitas capaian yang sulit diungkap. Pedoman prakerin di SMK tidak mengungkap kualitas, seperti relevansi lokasi dengan keahlian, ketercukupan visitasi, pengetahuan awal yang dimilki siswa (entry knowledge).

Pencapaian standar kompetensi lulusan perlu dikritisi karena standar yang tidak jelas mengarah pada ukuran saat pembelajaran atau jauh setelah kelulusan pembelajaran. Ambiguitas tentang standar kompetensi lulusan menjadi saran uatama untuk didiskusikan.

Pencapaian sasaran utnuk standar Pendidik dan Tenaga Kependidikan pada kualifikasi tenaga pendidik menduduki skor tertinggi, mungkin ada kaitannya dengan kemudahan akses pendidikan S1 di Daerah Istimewa Yogyakarta. Permasalahan yang mendasar adalah tingginya skor miss-match karena pengelompokkan pendidik di kota dan daerah, guru mapel produktif dan mapel adaptif-normatif, fleksibili- tas guru wanita, dan masalah di sekitar guru bantu.

Peran universitas khususnya yang mengemban peran wider mandate adalah menyiapakan ketersediaan guru kejuruan yang memiliki kinerja bagus karena latar belakang pendidikan, ditambah pelatihan di perguruan tinggi tersebut, membawa ke arah semakin dekatnya jarak antara harapan dan kenyataan pada tiap standar.

Ketersediaan sarana prasarana tidak maksimal, biasanya terjadi pada keberadaan dan kelengkapan Ruang Pembelajaran Khusus, pada SMK yang mengalami pemekaran interdisipliner; seperti semula sekolah berintikan SMK Teknologi lalu berkembang kearah pendirian program keahlian Bisnis Manajemen sehingga menyelenggarakan pendidikan Teknologi dan Bisnis Manajemen; semula berintikan Bisnis Manajmen berkembang ke arah Pariwisata sehingga menyelenggarakan Bisnis Manajemen dan Pariwisata, dan sebagainya. Efek domino yang bergulir pada perubahan konstelasi program keahlian menjadikan tidak terpenuhinya rasio buku ajar. Dinamika program keahlian terjadi dengan cepat, karena struktur program dalam format SMK, bukan lagi STM, SMEA, SMPP, dan SMKK.

Pencapaian standar pengelolaan tidak maksimal karena kelemahan administrasi pelaksanaan kegiatan dan kelemahan manajerial di SMK. Kelemahan administrasi dan manajerial SMK terjadi pada pelaksanaan PBM, kesiswaan, kurikulum dan pembelajaran, tendik, sarpras, keuangan dan pembiayaan, budaya dan lingkungan, serta 
peran serta masyarakat. Apalagi kelemahan pengelolaan sistem manajemen mutu, keberadaan bursa kerja khusus yang profesional, dan kerjasama dunia usaha dan dunia industri akan memperparah kondisi. Sebagai contoh, karena program keahlian/sekolah belum memiliki pengelolaan sistem manajemen mutu yang baik, kerjasama dunia usaha dan dunia industri, dan bursa kerja khusus belum bisa berjalan.

Pada standar pembiayaan terjadi pembiasan karena aturan sebatas prosedur dan mekanisme, tetapi tidak diikuti dengan pembiayaan untuk Standar Pelayanan Minimum, sehingga pemenuhan standar pembiayaan dapat mentolerir kelemahan struktur pembiayaan. Hal yang memperberat adalah ketiadaan subsidi silang, ternyata masih separuh yang menjadikan komitmen membantu si miskin baru sebatas wacana.

Pencapaian sasaran standar penilaian terjadi karena penyelenggaraan yang tidak maksimal, serta tekanan manajemen pada berbagai level. Pemahaman konsep penilaian sudah bagus, tetapi implementasi di lapangan terjadi sebatas memenuhi persyaratan administratif semata. Ini yang menjadikan nilai terendah standar penilaian pada ketidakmampuan menggunakan hasil penilaian sebagai dasar diagnostik belajar siswa dan proses pembelajaran.

Secara keseluruhan dapat disimpulkan bahwa tidak terpenuhinya Standar Nasional Pendidikan disebabkan ketidaktahuan pengelola sekolah, ketidaktertiban administrasi pendataan kegiatan sekolah, kekurangan aktivitas pendukung proses pendidikan, kekurangan tendik sekolah, dan kekurangan prasarana sekolah.

\section{PENUTUP}

\section{Kesimpulan}

Pencapaian tiap Standar adalah sebagai berikut Standar Isi $=0.71$; Standar Proses $=0.66$; Standar Komptensi Lulusan $=0.51$; Standar Tendik $=0.69$; Standar Sarpras $=0.70$; Standar Pengelolaan $=0.67$; Standar Pembiayaan $=0.83$; dan Standar Penilaian $=0.74$. Rata-rata pencapaian dari kedelapan standar tersebut adalah sebesar 0.69 , dengan asumsi bahwa tiap standar memiliki nilai yang setara terhadap nilai keseluruhan.

\section{Saran}

Pembinaan sekolah yang hakikatnya adalah upaya pemenuhan standar merupakan tanggung jawab yang bertingkat, sejak sekolah, dinas pendidikan kabupaten/kota, dinas pendidikan provinsi, pusat, dan lembaga pendukung lainnya. Level pertama adalah pembinaan di tingkat sekolah, jurusan, atau program keahlian. Pembinaan di tingkat ini bermakna untuk mengidentifikasi kekurangan dan kelebihan yang dimiliki oleh program keahalian/sekolah tersebut. Level kedua adalah pembinaan pendidikan di tingkat Dinas Pendidikan Kabupaten/Kota. Pada posisi ini peran stake holder sangat kuat karena penentuan Kepala Sekolah berada dipimpinan daerah (Bupati/ Walikota). Kerentanan kedua adalah Kepala Daerah tidak dapat bersifat obyektif. Level ketiga, pembinaan berada di tangan Dinas Pendidikan Provinsi, Lem- 
baga Penjaminan Mutu Pendidikan (LPMP). Pemenuhan standar di tingkat provinsi bernuansa konsultatif, karena konsentrasi anggaran pembinaan tidak berada di tingkat ini. Level keempat, pembinaan di Direktorat maupun Direktorat Jenderal di tingkat pusat. Hampir di semua level pembinaan di sekolah, pemda, maupun pemerintah pusat dominan pada sekolah negeri, dan sebagian kecil sekolah swasta. Fakta di lapangan berbeda, sekolah swasta lebih banyak dari sekolah negeri.

Kekhasan sekolah memberikan warna tersendiri dalam pemenuhan delapan standar nasional.Pembinaan sekolah negeri dilakukan secara bertingkat dan berujung akhir pada Kepala Sekolah. Pembinaan sekolah swasta bergantung pada dua pihak. Pemenuhan standar isi, proses, penilaian, dan kompetensi lulusan berada di skeolah, sedang pemenuhan standar tendik, sarpras, pengelolaan, dan pembiayaan berada di tangan Yayasan Penyelenggara. Pembinaan sekolah swasta berorientasi bisnis, biasanya jelas tercantum pada Anggaran Dasar dan Anggaran Rumah Tangga (AD/ ART) sekolah. Sekolah swasta yang berorientasi keagamaan memiliki dinamika sendiri. Pengelolaan sekolah Muhammadiyah terletak pada yayasan atau badan wakaf secara kolektif, sekolah Ma'arif Nahdhatul Ulama bergantung individu tokoh karismatik (Pak Kyai, Bu Nyai, Ajengan), sedangkan pembinaan pada Sekolah Katolik dan Kristen tentu saja berbeda-beda.

\section{UCAPAN TERIMAKASIH}

Terimakasih saya ucapkan kepada Badan Akreditasi Nasional Sekolah/ Madrasah (BAN SM) dan Badan Akreditasi Provinsi Sekolah/Madrasah (BAP SM) Provinsi DIY yang telah memberi peluang untuk menggunakan data akreditasi yang tersedia di kedua kantor tersebut. Terima kasih juga saya ucapkan kepada Dewan Redaksi Jurnal Cakrawala Pendidikan yang telah memberi saran bagi perbaikan artikel ini.

\section{DAFTAR PUSTAKA}

Badan Akreditasi Nasional Sekolah/ Madrasah. 2009. Perangkat Akreditasi SMK/SMK: Berdasar Peraturan Menteri Pendidikan Nasional Nomor 13 Tahun 2009.

Badan Akreditasi Nasional Sekolah/ Madrasah. 2007. Peraturan Menteri Pendidikan Nasional Republik Indonesia Nomor 113 Tahun 2007 tentang Standar Kepala Sekolah/ Madrasah.

Badan Akreditasi Nasional Sekolah/ Madrasah. 2007. Peraturan Menteri Pendidikan Nasional Republik Indonesia Nomor 20 Tahun 2007 tentang Standar Penilaian Pendidikan.

Badan Akreditasi Nasional Sekolah/ Madrasah. 2007. Peraturan Menteri Pendidikan Nasional Republik Indonesia Nomor 16 Tahun 2007 tentang Standar Kualifikasi Akademik dan Kompetensi Guru. 
Badan Akreditasi Nasional Sekolah/ Madrasah. 2007. Peraturan Menteri Pendidikan Nasional Republik Indonesia Nomor 19 Tahun 2007 tentang Standar Pengeloaan Pendidikan untuk Satuan Pendidikan Dasar dan Menengah.

Burko, H., Wolf, S.A., Simon, G., dan Uchiyama, K.P. 2003. "Schools in Transition: Reform Efforts and School Capacity in Washington Sate" Educational Evaluation and Policy Analysis. Volume 25, No 2, hlm. 171-201.

Chatterji, M. 2008. "Synthesizing Evidence From Impact Evaluations in Education to Inform Action" Educational Researcher. Volume 37. Number 1. Hlm. 23.

Cohen, D.K., Raudenbush, $\mathrm{S}$ dan Deborah, L.B. 2003. "Resources, Instruction, and Research " Educational Evaluation and Policy Analysis. Volume 25. No 2, Hlm. 119-120.

deWitt J. dan Hohentein, J. 2010. " School trips and Classroom Lesson: An investigation into teacher-student talk to setting"
Journal of Research in Science Teaching. Volume 47, April 2010, Hlm. 454-470.

Gaff, J. 2010. Academic Freedom and Accreditation. Paper on Annual Conference Council for Higher Education Accreditation. Washington DC: 27 January 2010.

James, C. and Vince, R. 2001. "Developing the leadership capability of head teachers" Journal of the British Educational Management $\mathcal{E}$ Administration Society. Thousands Oaks. CA: Sage Publications, pp 313-316.

Purwaningsih, Y.U. 2008. "Memompa motivasi Berprestasi Siswa melalui Pembelajaran Biologi Berbasis Proyek dengan Jejak Kasus". Jurnal Ilmiah Sagasitas. Dinas Pendidikan Provinsi DIY.

Slavin, R. 2008. "Evidence Based Reform in Education: Which Evidence Counts?" Educational Researcher. Volume 37, Number 37. Number 1, hlm. 4-5. 